\title{
Decision-making on loan services of small and medium enterprises (SMEs) in agrarian areas of North-Eastern Thailand
}

\author{
Pisit Potjanajaruwit ${ }^{1, *}$ \\ ${ }^{1}$ FMS, Suan Sunandha Rajabhat University, 1 U-Thong Nok rd, 10200, Dusit, Bangkok, Thailand
}

\begin{abstract}
The purpose of this research was to study the quality and standards of work that influence the operational efficiency of Small and Medium Enterprises in the construction business in Thailand. The data was gathered from 400 construction business entrepreneurs, 342 of which were respondents of an online questionnaire and the other 58 were out of 80 respondents to a questionnaire sent by post. The result revealed that quality and standards of work had effects towards the efficiency of the business. Having been granted permission to do construction from a provincial office of public works was found to affect their benefits and customers' satisfaction with statistical significance. It was also found that the use of good-quality construction materials and having construction completed on the requested schedule had an effect towards the business's revenue at the statistical significance level of 0.05 .
\end{abstract}

\section{Introduction}

Small and Medium Enterprises (SMEs) may include businesses in the manufacturing industry, whole sale and retail businesses, and the service industry. These small and medium-sized enterprises are an important foundation for social development in the real sector [1]. However, at present, a total of 9,216 small and medium enterprises have already ceased to operate. Out of this number, the small and medium-sized enterprises in construction were businesses found to terminate the most.

These businesses, which deal with construction projects of personal homes or commercial buildings and fall under the category of Small and Medium Enterprises in Service sector, were mostly faced with problems from personal qualities, management ability, network of enterprises and business, and the work quality and standards of the entrepreneurs themselves - all of which showed an effect on the efficiency of the business operations as a whole. Moreover, they were also affected by major global problems such as economic crises and rising petroleum prices resulting in higher costs of materials such as steel bars and cement that came from higher shipping costs. The changes in interest rates, inflation, unemployment, wage control, etc, were also factors with effects towards work quality and standards of all construction business operators. Furthermore, with the change of climate, they were also affected by natural disasters such as flooding, as the early stages

*Corresponding author: pisit.po@ssru.ac.th 
of construction work are usually done in an open outdoor area. When it rains, some parts of the construction process might not be able to continue, for instance pile foundation, cementing the masonry for building structure. This results in construction delays and being unable to finish the project as planned, which affected the success rate and operational efficiency of the business. Faced with the aforementioned problems, many construction business operators, who had accepted the work contract from their employer yet could not continue their projects, chose to abandon the work and closed down their business. This also affected a group of consumers who had already paid for the construction of a house though it was not completed or did not meet the agreed contract. These consumers had to file complaints and demand fairness from relevant agencies, which in turn, also affected the entrepreneurs with an image of low credibility and professional responsibilities, making it very difficult to get clients to trust them as before [2].

From the reasons mentioned above, it can be seen that the work quality and standards of Small and Medium Enterprises in the construction business are absolutely necessary. Therefore, this study aimed to explore the quality and standard of work that influence the operational efficiency of Small and Medium Enterprises in the construction business in Thailand.

\section{Methodology}

In conducting research on the quality and standards of the work of Small and Medium Enterprises in the construction business in Thailand, the research methodology was determined respectively according to the following issues: 1. Population and Sample Size 2. Study Tools 3. Data Collection and 4. Data Analysis and Statistics Used [3].

\subsection{Determination of Population and Sample Size}

1. Population used in the research were entrepreneurs of Small and Medium Enterprises in the construction businesses in Thailand. The term entrepreneur means an individual who owns a business by starting it and manages it by themselves. Without including subcontractors, there were a total of 27,848 entrepreneurs [4].

2. The sample group in this study included 400 entrepreneurs of Small and Medium Enterprises in the construction business in Thailand who were randomly selected from the population using the Yamane Formula (1967, p. 886) [5]. The selection methods used were probability sampling and systematic random sampling. The business owners were defined as a sampling unit, totalling 400 samples.

$$
n=\frac{N}{1+N e^{2}}=\frac{27,848}{1+27,848(0.5)^{2}}=400
$$

Table 1. Small and medium enterprises in the construction business of Thailand as classified by region [6].

\begin{tabular}{|l|c|c|c|}
\hline $\begin{array}{c}\text { Small and medium enterprises in the } \\
\text { construction business of Thailand as } \\
\text { classified by region }\end{array}$ & $\begin{array}{c}\text { Population } \\
\text { size }\end{array}$ & $\begin{array}{c}\text { Sample } \\
\text { size }\end{array}$ & Percentage \\
\hline 1. Central Region & 3.895 & 64 & 15.18 \\
\hline 2. Southern Region & 6.338 & 83 & 21.01 \\
\hline 3. Northern Region & 6.020 & 79 & 20.25 \\
\hline 4. Eastern Region & 1.684 & 22 & 5.04 \\
\hline 5. Northeastern Region & 12.240 & 160 & 40.50 \\
\hline \multicolumn{1}{|c|}{ Total } & $\mathbf{3 0 . 1 7 7}$ & $\mathbf{4 0 0}$ & $\mathbf{1 0 0}$ \\
\hline
\end{tabular}




\subsection{Creation of the study tool}

The tool used to collect data was a questionnaire which was built according to the objectives and conceptual framework of the study. The questionnaire was checked for the following qualities:

- Content Validity: The tool was checked by 3 experts for its consistency between the questions and the objectives and the content of the study, for which its IOC (Index of item Objective Congruence) was found to be between. 6-1.0, showing that all the questions were valid.

- Reliability: It was checked for reliability through Cronbarch's alpha coefficient which was found to be between 0.83-0.95.

\subsection{Data collection}

The collection of data including characteristics of Small and Medium Enterprises came from two 2 sections; 3.1 Primary data: from the 400 questionnaires answered by the sample groups of entrepreneurs of Small and Medium Enterprises. 58 of the 80 questionnaires sent by post were answered, while the other 342 questionnaires were responded to online. 3.2 Secondary data: obtained from researching and collecting of data from textbooks, documents, and related studies from online databases.

\subsection{Data analysis and statistics used}

Analysis of general data of entrepreneurs and enterprises: the statistics used were descriptive statistics such as frequency and percentage.

Analysis of human resource management and increase of productivity: statistics used were descriptive statistics such as mean and standard deviation. The data was presented in tabular form along with the explanation and summary of the research results.

The test of research hypothesis: The statistics used were inferential statistics using Chisquare test, for which results and discussion will be present further in the study.

\section{Result}

From the analysis, it was found that the quality and standards of their work were found at a high level with an average of 4.20 and a total standard deviation of 0.51 . "The land-filling materials used is of a non-hazardous nature towards health and stability of the foundation of the structure." was found as the item with a mean of 4.37, at the highest level, and standard deviation of 0.62 . It was followed by "The quality of construction materials used meets the standards as specified in Bangkok Metropolis's regulations of constuction control." with a mean of 4.32, also at the highest level, and a standard deviation of 0.76 . "An engineer is assigned to control the on-site work during the construction and to be responsible for the construction" was found with a mean of 4.27 , the highest level, and a standard deviation of 0.79. "The construction is permitted by Bangkok Metropolitan Administration." was found with a mean of 4.22, at the highest level, and a standard deviation of 0.81 . "The building or structure is built in accordance with Bangkok Metropolis's regulations of constuction control." was also found with the same mean of 4.22, at the highest level, with a standard deviation of 0.75 . "The contruction plan is drafted using the ratios specified by the Department of Public Work." was found with a mean of 4.04, a high level, and a standard deviation of 0.62 . The last ítem, "The construction is completed within time limit requested." was found with a mean of 3.79 , at a high level, and standard deviation of 0.78 . 
Table 2. Quality and standards of work with effects on a business's success $(n=400)$.

\begin{tabular}{|l|c|c|}
\hline \multicolumn{1}{|c|}{ Work quality and standards } & Mean & $\begin{array}{c}\text { Standard } \\
\text { Deviation }\end{array}$ \\
\hline $\begin{array}{l}\text { 1. The construction is permitted by Bangkok Metropolitan } \\
\text { Administration. }\end{array}$ & 4.22 & 0.81 \\
\hline $\begin{array}{l}\text { 2. The building or structure is built in accordance with Bangkok } \\
\text { Metropolis's regulations of constuction control. }\end{array}$ & 4.22 & 0.75 \\
\hline $\begin{array}{l}\text { 3. The quality of construction materials used meets the standards as } \\
\text { specified in Bangkok Metropolis's regulations of constuction } \\
\text { control. }\end{array}$ & 4.32 & 0.76 \\
\hline 4. The construction is completed within time limit requested. & 3.79 & 0.78 \\
\hline $\begin{array}{l}\text { 5. An engineer is assigned to control the on-site work during the } \\
\text { construction and to be responsible for the construction. }\end{array}$ & 4.27 & 0.79 \\
\hline $\begin{array}{l}\text { 6. The land-filling materials used are of a non-hazardous nature } \\
\text { towards health and stability of the foundation of the structure. }\end{array}$ & 4.37 & 0.62 \\
\hline $\begin{array}{l}\text { 7. The contruction plan is drafted using the ratios specified by the } \\
\text { Department of Public Work. }\end{array}$ & 4.04 & 0.62 \\
\hline
\end{tabular}

The analysis also revealed that the quality and standards of their work had an influence on the operational efficiency of these Small and Medium Enterprises in the construction business in Thailand. The results of the hypothesis testing can be summarized that the quality and standards in the item of "The construction is permitted by the Department of Public Works and Town \& Country Plannning." (Q1) had an effect towards the operational efficiency of these construction businesses in terms of profits and revenue of the business (Fin1-3) with values of $\mathrm{X} 2=44.92 *$ and $40.84 *$ respectively. It also affected the operational efficiency of these construction businesses in terms of customer satisfaction the number of both existing and new customers (Cus1-3), with values of X2 $=29.89^{*}, 42.17^{*}$ and $54.66^{*}$ respectively and statistical significance at the level of 0.05 .

Table 3. The test results of $\mathrm{H} 1$ hypothesis showing that quality and standards of work showed an effect on the success of the construction business.

\begin{tabular}{|c|c|c|c|c|c|c|}
\hline \multirow{2}{*}{ Variables } & & & & & & \\
\hline & Fin1 & Fin2 & Fin3 & Cus1 & Cus2 & Cus3 \\
\hline Q1 & $44.92^{*}$ & $40.84^{*}$ & 6.56 & $29.89^{*}$ & $42.17^{*}$ & $54.66^{*}$ \\
\hline Q2 & $22.41^{*}$ & $40.43^{*}$ & 6.94 & $16.94^{*}$ & $44.14^{*}$ & $19.56^{*}$ \\
\hline Q3 & $17.74^{*}$ & $27.41^{*}$ & $34.27^{*}$ & $44.44^{*}$ & $19.48^{*}$ & $20.31^{*}$ \\
\hline Q4 & $80.22^{*}$ & $95.73^{*}$ & $38.16^{*}$ & $73.49^{*}$ & $44.14^{*}$ & $43.80^{*}$ \\
\hline Q5 & $59.38^{*}$ & $73.83^{*}$ & $33.76^{*}$ & $72.10^{*}$ & $93.76^{*}$ & $49.89^{*}$ \\
\hline
\end{tabular}

Building plans (Q2) that were drafted correctly according to the regulations of the Department of Public Works and Town \& Country Planning regarding construction control were found to affect the construction businesses in terms of profit and revenue (Fin1-2) with the values of $\mathrm{X} 2=22.41 *$ and $40.43 *$ respectively. The correct plan (Q2) according to the regulations of the Department of Public Works and Town \& Country Planning regarding construction control was also found to affect customer satisfaction and the number of existing and new customers (Cus1-3) with the values of X2 $=16.94^{*}, 44.14^{*}$, and $19.56^{*}$ respectively and statistical significance at the level of 0.05 .

The use of standard quality construction materials (Q3) was found to affect the operational efficiency of the construction businesses in terms of profit, revenue, and costs (Fin1-3) with the values of X2 $=17.74 *, 27.41^{*}$, and $34.27^{*}$ respectively. Moreoever, the use of standard quality construction materials (Q3) also affected the satisfaction of 
customers and the number of existing and new customers (Cus1-3) with the values of X2 = $44.44^{*}, 19.48^{*}$, and $20.31 *$ respectively and statistical significance at the level of 0.05 .

The construction being completed within the time limit requested (Q4) was found to affect the operational efficiency of the construction businesses in terms of profit, revenue, and cost of business (Fin1-3) with the values of X2 $=80.22^{*}, 95.73^{*}$ and $38.16^{*}$ respectively. Having the construction completed on within the time limit requested (Q4) also affected the satisfaction of customers and the number of both existing and new customers (Cus1-3) with the values of X2 $=73.49 *, 44.14 *$, and $43.80 *$ respectively and statistical significance at the level of 0.05 .

Assigning an engineer to control the on-site work during construction and to be responsible for the construction (Q5) was found to affect the operational efficiency of the construction businesses in terms of profit, revenue, and costs of the business (Fin1-3) with the values of $\mathrm{X} 2=59.38^{*}, 73.83^{*}$, and $33.76^{*}$ respectively. Assigning an engineer to control the on-site work during the construction and to be responsible for the construction (Q5) also affected customer satisfaction and the number of both existing and new customers (Cus1-3) with the values of X2 $=72.10^{*}, 93.76^{*}$, and $49.89^{*}$ respectively and statistical significance at the level of 0.05 .

\section{Discussion}

From the analysis, it was found that the quality and standards of work had an influence on the operational efficiency of Small and Medium Enterprises in the construction business in Thailand. The construction being completed within the time limit requested (Q4) and assigning an engineer to control the on-site work during construction and to be responsible for the construction (Q5) were found to have effects with statistical significance at the level of $0.05=80.22 *$ and $59.38 *$ accordingly. This means having construction completed on time, having an engineer assigned to control the on-site work during construction, and using land-filling materials of a non-hazardous nature towards health and stability of the foundation of the structure, were found to affect the businesses' profits, revenue, and costs. This corresponds to the intel from the [7].

That, in general, construction costs consist of 2 types of expenses; (1) direct cost including labor and material costs used in construction and (2) indirect costs - such as facilitation fees, loan interests, and taxes. Altogether, these two categories affect operating costs, revenue, and profits of the contractors as they also operate under govermentrecommended medium-price in construction, which is constantly adjusted in accordance with economic conditions. This corresponds with this statement [8]. The contractor is responsible to the employer who has already paid for the work and shall not leave work unfinished. They must complete the work within the agreed deadline without withdrawing advance money unnecessarily. The construction materials must be of good quality and standards. Land-filling materials used must be appropriate, for example, clay must be used to fill the base. The quality of steel work must be maintained through the use of full-sized steel bars that can support a great weight.

The PVC pipes used must be strong. Rust-protection primer must be used in painting process. Good entrepreneurs should assign efficient engineers to control the quality and standards to meet the construction contract. Punctuality is also another important aspect of the construction process. For the employer to be satisfied, the construction business operator should deliver the work according to the agreed period specified in the contract. This also helps prevent being fined due to late delivery of work which will negatively affect the reliability and efficiency of the business operations, both financially and reliably. In addition, [6]. it was stated in the construction control regulations that; (1) The building construction permit recipient must keep the permit, construction plan, and one copy of the 
construction items list at the construction site, so the civil works technician, whose work is to inspect the building, can always assess them.

The construction must also be finished within the time specified in the permit. (2) There must be a supervisor assigned who is responsible for the construction to be conducted in accordance with the permission and to ensure safety for the workers involved. If the supervisor cannot be permanently stationed on-site, any orders of the civil works technician responsible for the inspection of the building given to the construction supervisor shall be deemed given to the owner of the building themselves. (3) If the inspecting civil works technician finds the building to be faulty from the construction plan, construction list, or conditions as specified in permit, the owner of the building or the contractor must correct the issues within the time limit.

After the deadline has passed, if the amendment has not been completed, legal proceedings shall be made in accordance with the laws on construction control. (4) The building construction material must have the quality as specified by the construction list and spreasheets. (5) In piling process for building foundations, suitable piles for the weight of the building must be used. (6) Construction of a building that is close to general public space can only proceed when the protection measures against falling objects that may be harmful to passers-by near the construction site are applied. It was explained [9] that the standards in the construction business in construction of buildings or structures include the selection of construction materials of good quality and standards. For standards, they can be divided into many levels, from the factory standards, national standards, to international standards, etc. Thus, each organization must have a system of quality control for specifications such as shapes, durability, safety, etc.

Additionally, another important and essential factor for the businesses from the customers' point of view is the quality of the products and the service quality. Projects must be delivered on time as required by the customer without any problems. Construction planning and delivery of finished projects to customers require special attention, otherwise they can damage the business system and cause customers' dissatisfaction or even loss of customers which will adversely affect the business.

This is in accordance with a statement [10] which explains that the work quality and standards of a construction business is determined from the raw materials and other materials used in the construction $[11,12,13]$. All construction materials used in the construction must be standardized, including the clay used for landfill, pilling materials (concrete, wood), cement, steel, sand, stone, tiles, etc. At present, some types of construction materials have their price adjusted up and down according to economic conditions [14]. All these can affect the efficiency of operations in terms of finance, both in profits and in operating costs and at the same time also affects the level of customer satisfaction.

Therefore, entrepreneurs should have civil engineers assigned to control the details regarding the quality and quantity of the materials used in construction. There should also be surveying of prices and the standard of materials from different sources in order to compare construction material prices, which should be carried out regularly in order to acquire up-to-date information on the prices of construction materials in the market that are constantly changing. This information can also be used in determining the specifications and standards of the material in order to achieve qualified work for customer satisfaction.

\section{References}

1. J.B. Yang, S.C. Peng, Building and Environment 43(4), 458-468 (2008)

2. D. Hidıroğlu, Procedia Computer Science 158, 844-851 (2019) 
3. B.H. Widayanti, A. Yuniarman, S.A.P. Lestari, S.R. Yunianti, E\&ES 447(1) (2020)

4. Office of Small and Medium Enterprises Promotion, Gross Domestic Product of Thai SMEs (2018) https://www.nationthailand.com

5. T. Yamane, Sampling Formula (E-Book, 1967)

6. K. Park, H.W. Lee, K. Choi, S.H. Lee, International Journal of Civil Engineering 17(3), 305-321 (2019)

7. P.V. Ingle, G. Mahesh, International Journal of Construction Management 1-12 (2020)

8. S. Nugraha, Y. Latief, International Journal of Engineering and Advanced Technology 8(5), 654-661 (2019)

9. H.G. Bayhan, S. Demirkesen, E. Jayamanne, IOP Conference Series: Materials Science and Engineering 471(2), 022002 (2019)

10. S. Sheikhesmaeili, S. Hazbavi, Model Construction of Engagement and Outcomes in Consumers Food Life: Evidence from C stores Customers (2016)

11. D. Ushakov, International Journal of Environmental and Science Education 18 (2016)

12. D. Ushakov, Actual Problem of Economy 1 (2016)

13. P. Křibíková, M. Tichá, B. Poczatková, EUrASEANs 4(5), 19-27 (2017)

14. A. Př́ivara, Migration Letter 16(2), 245 - 254 (2019) 